American Journal of Pharmaceutical Education 2020; 84 (10) Article 7270.

\title{
RESEARCH
}

\section{Assessment of Pharmacy Student Perceptions Toward Common Stigmas Associated with Persons Living with HIV}

\author{
Kenric B. Ware, PharmD, MBA \\ South University School of Pharmacy, Columbia, South Carolina \\ Submitted July 13, 2018; accepted June 22, 2020; published October 2020.
}

Objective. To analyze pharmacy students' views of societal stigmas often facing persons living with human immunodeficiency virus (HIV).

Methods. A 20-item survey conducted across a dual-campus school of pharmacy examined students' approval of societal aspects of the lives of persons living with HIV. Pharmacy students anonymously exchanged completed survey instruments to learn about peers' viewpoints. Survey instruments were analyzed and ranked by most commonly occurring responses and gender designations. Chi square tests were used for statistical analyses, with $p<.05$ considered significant.

Results. Over three years, 260 female students and 104 male students (364 total) completed the survey. Approximately one fifth of the study sample stated that they did not have a problem placing their children (if applicable) in a daycare center with children who were living with HIV. Greater than one third of the students in the study sample were not opposed to placing their elderly parents (if applicable) in a facility that included residents living with HIV. Fewer female than male students had reservations about couples living with HIV being allowed to have children. Male students were less averse than female students to having their name and picture associated with HIV prevention on the internet.

Conclusion. This study revealed that some pharmacy students held stigmatizing beliefs regarding persons living with HIV. The discriminatory views of participants in this study sample may directly or indirectly affect health outcomes of persons living with HIV. To better address health care challenges within this community, Doctor of Pharmacy programs should provide sustainable opportunities for students to explore their own HIV biases and additional education about the difficulties that persons living with HIV encounter.

Keywords: HIV, stigma, questionnaire

\section{INTRODUCTION}

Persons living with human immunodeficiency virus (HIV) are known to experience emotional duress and a variety of psychological stressors that are often exacerbated by having to deal with societal stigmas associated with the infection. ${ }^{1}$ Fortunately, scientific insights into the lifecycle of HIV and corresponding treatment modalities have transformed a diagnosis that previously equated to a death sentence into a manageable chronic health condition..$^{2-4}$ While long-term survival of persons living with HIV has improved, opportunities remain for professionals and trainees, particularly pharmacists and pharmacy students, to become more familiar with the psychosocial challenges that persons living with HIV routinely face. It is important for them to understand some

Corresponding Author: Kenric B. Ware, South University School of Pharmacy, 10 Science Ct., Columbia, SC 29203. Tel: 803-935-9695. Email: kbware@southuniversity.edu common difficulties that persons living with HIV encounter in relation to procreation potential, parental responsibilities, and acceptance in educational settings. ${ }^{5-9}$ There are also issues relating to sexuality, drug abuse, and mental health of which students should be aware. ${ }^{10-12}$ By gaining a better understanding of these situational complexities, Doctor of Pharmacy (PharmD) students can better understand the plight of persons living with HIV, hopefully leading them to provide more compassionate and supportive patient care.

Learning methods that engage students in activities that are directed toward the affective domain and foster self-reflection can effectively shape student perceptions of patient care. ${ }^{13}$ The Accreditation Council for Pharmacy Education Standards 2016 state the expectation that colleges and schools of pharmacy shall cultivate "personal and professional maturity consistent with the Oath of the Pharmacist." "14 Classroom activities should guide students to develop sound clinical reasoning and decision- 


\section{American Journal of Pharmaceutical Education 2020; 84 (10) Article 7270.}

making skills that are grounded in empathy and compassion. ${ }^{14}$ It is also important to acknowledge and address erroneous assumptions or unfounded apprehensions that students might harbor toward disenfranchised patients, compelling them to provide the same standard of care to all patients. $^{13,15-18}$

Because students' exposure to persons living with HIV varies, educators may need to use creative approaches to promote greater awareness among students of the impact that an HIV diagnosis can have on persons living with HIV. ${ }^{13}$ Instructional modalities have been designed to educate health care professionals and students about myths and inequities experienced by persons living with HIV. ${ }^{19-25}$ The classroom can serve as a versatile training ground for addressing students' HIV stigmatizing beliefs. ${ }^{15-18,26,28}$ Panel discussions that feature persons living with HIV or health care practitioners who have direct involvement with the care of patients with HIV add elements of realism and practicality to lectures. Faculty members can also develop in-class activities that enhance student awareness about HIV disparities. ${ }^{13}$ Patient case presentations may be used to raise general awareness about relationship and cultural structures that predispose underserved groups to acquiring HIV. ${ }^{16,29-34}$ Case studies can highlight preferred management strategies that affirm and reassure persons living with HIV, especially those who feel that they have been ostracized. ${ }^{26}$ Probing questions that require students to face their misgivings regarding persons living with HIV can challenge students to expand their perspective about the roles that they might play as health care providers serving the HIV population. ${ }^{15-18,26,28}$

The purpose of this project was to increase sensitivities among pharmacy students to the plight of persons living with HIV and to assess pharmacy students' perspectives toward various stigmas that regularly confront this patient population.

\section{METHODS}

This study was conducted at an institution that offers an accelerated three-year PharmD program across two campuses: one in Columbia, SC, and one in Savannah, GA. The students from each campus participated in an inclass activity that involved completion of a 20 -item survey about their perceptions of persons living with HIV, followed by an interactive discussion. The survey instrument was developed by the author after consulting specialists with expertise in dealing with persons living with HIV, including an HIV peer adherence coach, an HIV peer navigator, and a hepatitis C/HIV Pre-Exposure Prophylaxis (PrEP) program coordinator. These experts evaluated the survey items through the lens of scenarios they encounter in their professional roles and confirmed that the survey items were constructed in a manner that would foster meaningful self-assessment and group discussion about the implicit and explicit stigma that persons living with HIV face on a regular basis. All participants were enrolled in a five-credit infectious disease course during their first professional year of the PharmD program. Only students who were repeating the course and had previously completed the survey were excluded.

The survey consisted of 20 items which were divided into four categories: "I believe" statements, "I feel" statements, "I am comfortable with" statements, and "I avoid" statements. The survey was administered during an in-class activity conducted simultaneously across both campuses via video teleconferencing, allowing the author, who was physically present in Columbia, to facilitate the activity in both locations. The activity was conducted prior to students receiving any instruction in HIV pathophysiology or therapeutic management in order to accurately assess their foundational perceptions of what it is like to live with HIV. Also, they had not been previously exposed in the pharmacy curriculum to the psychosocial implications of caring for persons living with HIV.

At the start of the activity, students were instructed to refrain from writing their names or any other selfidentifying information on the survey instrument. Female and male students were offered a pink or blue survey sheet based on their personal representation of gender identity. For each of the 20 statements included in the survey instrument, students were told to circle "A" for agreement, "D" for disagreement, or leave it blank if they were not comfortable answering. After completing the survey instrument, which took about 30 minutes, students on each campus divided themselves into two groups by moving to either the front or back of the classroom, bringing their survey instrument with them. Once equally distributed, they were instructed to crumple the paper and toss it toward the other side of the room. Afterward, each student gathered a survey that had been anonymously completed by a classmate (without regard to whether it was pink or blue) and returned to their seat.

A 15- to 30-minute post-survey discussion began with the instructor reading each survey item and asking students to raise their hand if the survey they retrieved expressed agreement with the statement. Students were then encouraged to pose questions and/or interject comments relating to the respective statement. During the discussions, the instructor shared his professional insights from years of experience as a health care provider serving persons living with HIV. After the class period, all survey instruments were collected and analyzed to identify, for 
American Journal of Pharmaceutical Education 2020; 84 (10) Article 7270.

Table 1. Responses of Pharmacy Students Who Completed a Survey to Determine Their Perceptions Toward Common Stigmas Associated With Persons Living With HIV $(\mathrm{N}=364)$

\begin{tabular}{|c|c|c|c|}
\hline Item \# & Agree (\%) & Disagree (\%) & No Answer (\%) \\
\hline $\begin{array}{l}\text { 11. I am comfortable with counseling PLWH on } \\
\text { proper usage of their HIV medications. }\end{array}$ & 98.4 & 1.1 & 0.5 \\
\hline $\begin{array}{l}\text { 20. I avoid/would avoid engaging in sexual acts } \\
\text { with a PLWH whose viral load is } \\
\text { undetectable. }\end{array}$ & 95.9 & 3.4 & 0.7 \\
\hline 16. I avoid/would avoid dating PLWH. & 92.6 & 6.9 & 0.5 \\
\hline $\begin{array}{l}\text { 18. I avoid/would avoid placing my children in } \\
\text { a daycare center with children living with } \\
\text { HIV. }\end{array}$ & 79.4 & 19.8 & 0.8 \\
\hline $\begin{array}{l}\text { 14. I am comfortable offering medical advice to } \\
\text { a male living with HIV who is married to a } \\
\text { woman but has sex with men. }\end{array}$ & 72.8 & 26.4 & 0.8 \\
\hline $\begin{array}{l}\text { 10. I feel inexpensive co-payments should not } \\
\text { apply to HIV medications. }\end{array}$ & 72.3 & 26.9 & 0.8 \\
\hline $\begin{array}{l}\text { 13. I am comfortable with women sexually } \\
\text { assaulted by PLWH having abortions. }\end{array}$ & 71.4 & 27.2 & 1.4 \\
\hline $\begin{array}{l}\text { 15. I am comfortable with the idea of the } \\
\text { Surgeon General of the United States living } \\
\text { with HIV. }\end{array}$ & 69.8 & 28.6 & 1.6 \\
\hline $\begin{array}{l}\text { 19. I avoid/would avoid placing my elderly parents } \\
\text { in a facility with elderlies living with HIV. }\end{array}$ & 62.9 & 36.3 & 0.8 \\
\hline $\begin{array}{l}\text { 8. I feel people who knowingly contract HIV } \\
\text { should have to undergo psychological testing. }\end{array}$ & 61.3 & 38.5 & 0.2 \\
\hline $\begin{array}{l}\text { 3. I believe reducing the stigma associated with } \\
\text { HIV has lessened the severity of the disease. }\end{array}$ & 44.2 & 52.8 & 3 \\
\hline $\begin{array}{l}\text { 5. I believe a cure for HIV exists; however, it is } \\
\text { unavailable due to fear of financial losses. }\end{array}$ & 42.3 & 56.9 & 0.8 \\
\hline $\begin{array}{l}\text { 4. I believe health care workers living with HIV } \\
\text { should disclose their statuses to their patients. }\end{array}$ & 35.7 & 63.7 & 0.6 \\
\hline $\begin{array}{l}\text { 1. I believe couples living with HIV should not } \\
\text { have permission to bear children. }\end{array}$ & 30.5 & 69.2 & 0.3 \\
\hline $\begin{array}{l}\text { 9. I feel commercial sex workers (prostitutes) } \\
\text { deserve the highest quality of healthcare } \\
\text { services. }\end{array}$ & 28.9 & 70.9 & 0.2 \\
\hline $\begin{array}{l}\text { 12. I am comfortable with my name and picture } \\
\text { being associated with HIV prevention } \\
\text { efforts on the internet. }\end{array}$ & 14.8 & 83.5 & 1.7 \\
\hline 2. I believe PLWH should blame themselves. & 9.1 & 90.9 & 0 \\
\hline $\begin{array}{l}\text { 7. I feel too much government funding is } \\
\text { devoted to HIV research. }\end{array}$ & 8 & 91.2 & 0.8 \\
\hline $\begin{array}{l}\text { 17.I avoid/would avoid discussing HIV topics } \\
\text { with my family and/or friends. }\end{array}$ & 6.9 & 92.6 & 0.5 \\
\hline $\begin{array}{l}\text { 6. I feel expensive health services should omit } \\
\text { PLWH since they are at higher risk of dying } \\
\text { than the general population. }\end{array}$ & 5.2 & 94.5 & 0.3 \\
\hline
\end{tabular}

Abbreviations: HIV=Human Immunodeficiency Virus, PLWH=Persons Living with HIV

each item, the number of agree and disagree responses. The analysis also included noting the level of agreement for each item based on whether the respondent identified as male or female. A statistical comparison of the gender results for each of the 20 survey items was conducted using the chi-square test. All data analyses were conducted using the SPSS, version 24, (IBM, Armonk, NY) with significance defined as a $p$ value of $<.05$. 
American Journal of Pharmaceutical Education 2020; 84 (10) Article 7270.

Table 2. Differences in Responses of Pharmacy Students by Gender Who Completed a Survey to Determine Their Perceptions Toward Common Stigmas Associated With Persons Living With HIV (N=260 females and 104 males)

\begin{tabular}{|c|c|c|c|c|c|c|c|}
\hline \multirow[b]{2}{*}{ Item } & \multicolumn{3}{|c|}{ Females } & \multicolumn{4}{|c|}{ Males } \\
\hline & $\begin{array}{c}\text { Agree } \\
(\%)\end{array}$ & $\begin{array}{c}\text { Disagree } \\
(\%)\end{array}$ & $\begin{array}{c}\text { No Answer } \\
(\%)\end{array}$ & $\begin{array}{c}\text { Agree } \\
(\%)\end{array}$ & $\begin{array}{c}\text { Disagree } \\
(\%)\end{array}$ & $\begin{array}{c}\text { No Answer } \\
(\%)\end{array}$ & $\begin{array}{c}p \\
\text { value }\end{array}$ \\
\hline $\begin{array}{l}\text { 1. I believe couples living with HIV } \\
\text { should not have permission to bear } \\
\text { children. }\end{array}$ & 26.9 & 73.1 & 0 & 39.4 & 59.6 & 1 & .02 \\
\hline $\begin{array}{l}\text { 2. I believe PLWH should blame } \\
\text { themselves. }\end{array}$ & 7.3 & 92.3 & 0.4 & 13.5 & 86.5 & 0 & .70 \\
\hline $\begin{array}{l}\text { 3. I believe reducing the stigma } \\
\text { associated with HIV has lessened the } \\
\text { severity of the disease. }\end{array}$ & 40 & 59.2 & 0.8 & 54.8 & 36.5 & 8.7 & .01 \\
\hline $\begin{array}{l}\text { 4. I believe health care workers living } \\
\text { with HIV should disclose their } \\
\text { statuses to their patients. }\end{array}$ & 32.7 & 66.5 & 0.8 & 43.3 & 55.8 & 0.9 & .06 \\
\hline $\begin{array}{l}\text { 5. I believe a cure for HIV exists; } \\
\text { however, it is unavailable due to fear } \\
\text { of financial losses. }\end{array}$ & 41.2 & 58.5 & 0.3 & 45.2 & 52.9 & 1.9 & .41 \\
\hline $\begin{array}{l}\text { 6. I feel expensive health services should } \\
\text { omit PLWH since they are at higher } \\
\text { risk of dying than the general } \\
\text { population. }\end{array}$ & 6.2 & 93.8 & 0 & 2.9 & 96.1 & 1 & .21 \\
\hline $\begin{array}{l}\text { 7. I feel too much government funding is } \\
\text { devoted to HIV research. }\end{array}$ & 9.2 & 89.6 & 1.2 & 4.8 & 94.2 & 1 & .16 \\
\hline $\begin{array}{l}\text { 8. I feel people who knowingly contract } \\
\text { HIV should have to undergo } \\
\text { psychological testing. }\end{array}$ & 60 & 40 & 0 & 64.4 & 34.6 & 1 & .37 \\
\hline $\begin{array}{l}\text { 9. I feel commercial sex workers } \\
\text { (prostitutes) deserve the highest } \\
\text { quality of healthcare services. }\end{array}$ & 30 & 70 & 0 & 26.9 & 73.1 & 0 & .47 \\
\hline $\begin{array}{l}\text { 10. I feel inexpensive co-payments } \\
\text { should not apply to HIV medications. }\end{array}$ & 13.5 & 85 & 1.5 & 18.3 & 79.8 & 1.9 & .24 \\
\hline $\begin{array}{l}\text { 11. I am comfortable with counseling } \\
\text { PLWH on proper usage of their HIV } \\
\text { medications. }\end{array}$ & 98.1 & 1.5 & 0.4 & 99 & 0 & 1 & .21 \\
\hline $\begin{array}{l}\text { 12. I am comfortable with my name and } \\
\text { picture associated with HIV } \\
\text { prevention efforts on the internet. }\end{array}$ & 69.6 & 30 & 0.4 & 78.9 & 19.2 & 1.9 & .04 \\
\hline $\begin{array}{l}\text { 13. I am comfortable with women } \\
\text { sexually assaulted by men living with } \\
\text { HIV having abortions. }\end{array}$ & 71.2 & 27.3 & 1.5 & 72.1 & 26.9 & 1 & .92 \\
\hline $\begin{array}{l}\text { 14. I am comfortable offering medical } \\
\text { advice to a male living with HIV who } \\
\text { is married to a woman but has sex with } \\
\text { men. }\end{array}$ & 71.5 & 27.7 & 0.8 & 76 & 23.1 & 0.9 & .37 \\
\hline $\begin{array}{l}\text { 15. I am comfortable with the idea of the } \\
\text { Surgeon General of the United States } \\
\text { being a PLWH. }\end{array}$ & 68.1 & 30.4 & 1.5 & 73.1 & 24 & 2.9 & .25 \\
\hline 16. I avoid/would avoid dating PLWH. & 93.9 & 5.8 & 0.3 & 89.4 & 9.6 & 1 & .19 \\
\hline $\begin{array}{l}\text { 17. I avoid/would avoid discussing HIV } \\
\text { topics with my family and/or friends. }\end{array}$ & 6.5 & 93.1 & 0.4 & 7.7 & 91.4 & 0.9 & .68 \\
\hline
\end{tabular}


American Journal of Pharmaceutical Education 2020; 84 (10) Article 7270.

Table 2. (Continued)

\begin{tabular}{|c|c|c|c|c|c|c|c|}
\hline \multirow[b]{2}{*}{ Item } & \multicolumn{3}{|c|}{ Females } & \multicolumn{4}{|c|}{ Males } \\
\hline & $\begin{array}{c}\text { Agree } \\
(\%)\end{array}$ & $\begin{array}{c}\text { Disagree } \\
(\%)\end{array}$ & $\begin{array}{c}\text { No Answer } \\
(\%)\end{array}$ & $\begin{array}{c}\text { Agree } \\
(\%)\end{array}$ & $\begin{array}{c}\text { Disagree } \\
(\%)\end{array}$ & $\begin{array}{c}\text { No Answer } \\
(\%)\end{array}$ & $\begin{array}{c}p \\
\text { value }\end{array}$ \\
\hline $\begin{array}{l}\text { 19. I avoid/would avoid placing my } \\
\text { elderly parents in a facility with } \\
\text { elderlies living with HIV. }\end{array}$ & 64.6 & 34.6 & 0.8 & 58.7 & 40.4 & 0.9 & .29 \\
\hline $\begin{array}{l}\text { 20. I avoid/would avoid engaging in } \\
\text { sexual acts with a PLWH whose viral } \\
\text { load is undetectable. }\end{array}$ & 95.4 & 4.2 & 0.4 & 97.1 & 1.9 & 1 & .29 \\
\hline
\end{tabular}

Abbreviations: HIV=Human Immunodeficiency Virus, PLWH=Persons Living with HIV

\section{RESULTS}

The cumulative results for all participants from both campuses over the three-year study period are presented in Table 1. The listing of items in the table represents a rank order from highest to lowest degree of agreement. The listing of items in descending order based upon their levels of agreement was designed to highlight any noticeable trends within the four subcategories: "I believe," "I feel," "I am comfortable with," and "I avoid." Nearly $80 \%$ of the students in the study sample indicated that they would avoid placing their children (if applicable) in a daycare center where there were children living with HIV. Almost two thirds of the sample admitted that they would avoid placing their elderly parents (if applicable) in a facility that included residents living with HIV. About $25 \%$ of the sample expressed discomfort with offering medical advice to a male patient living with HIV who was married to a woman but had sex with men. No significant differences existed in student responses within each of the four categories assessed: "I believe," "I feel," "I am comfortable with," and "I avoid" statements.

Agreement data for male and female participants are presented in Table 2. Associated $p$ values indicate whether the two sets of data were statistically different. A greater percentage of male than female students believed that couples living with HIV should not be allowed to have children $(p=.02)$. Fewer female students were comfortable with having their name and picture associated with involvement in HIV prevention on the internet $(p=.04)$.

\section{DISCUSSION}

This study was designed to assess the perceptions of pharmacy students toward the psychosocial challenges facing patients with HIV. Evidence suggestive of stigmas toward persons living with HIV was reflected by the responses of the pharmacy student participants to several of the survey statements. Students were involved in an open discussion during which the perceptions of others were made apparent. The value of the instructional design was that students were able to share surveys anonymously and report someone else's responses. Fear of HIV transmission from interactions with persons living with HIV is a common concern among a variety of health-related student populations. ${ }^{17},{ }^{27-28}$ Literature reports of student opinions that persons living with HIV should be isolated in one form or another is disturbing. ${ }^{16,24,27}$ Similarly, students have been reported to believe that hospital beds should clearly denote a patient's HIV status. ${ }^{27}$ These observations suggest that cultural humility might need greater attention in health-related academic programs.

The recurring theme in this study of students not entrusting the care of their loved ones to community establishments that house individuals living with HIV was disconcerting. These disclosures speak to a glaring educational need to discuss and continually revisit verifiable routes of HIV transmission. Furthermore, avoidance in this respect should be addressed from the vantage point of unintentionally alienating a population already marginalized in certain realms of society. In addition, the subgroup of students in this study that expressed couples living with HIV should avoid attempts to have children was noteworthy. The lack of education from the school of pharmacy's curriculum prior to participating in this study, about how HIV medication therapy has evolved to make it possible for couples living with HIV to have children without HIV, might have contributed to these misgivings.

Male students in a previous study held more negative views toward homosexuals and homosexual interactions than female students. ${ }^{30}$ Evidence suggests the burden of HIV largely resides among homosexual populations. ${ }^{31}$ If male students in this study shared similar views toward homosexuals, and by extension persons living with HIV, this may explain their higher disapproval rates of couples 


\section{American Journal of Pharmaceutical Education 2020; 84 (10) Article 7270.}

living with HIV having children. Female students in a different setting reported having more cautious attitudes toward sexual risk behaviors than male students. ${ }^{32}$ Acquisition of HIV is primarily associated with high-risk sexual behaviors. ${ }^{31}$ If female students in this study had similar thoughts about sexual risk behaviors, this may speak to their hesitation toward personally identifying with HIV prevention efforts on the internet.

Students appeared to respond favorably to the instructional activities associated with this study and expressed that they perceived value in exploring the struggles that persons living with HIV face daily. The procedural tossing of paper was employed to randomly and anonymously distribute surveys in a unique, playful manner prior to the open discussion. Having students publicly reveal the responses of anonymous classmates fostered a frank, unguarded discussion. That might not have been the case if students were asked to report their own responses.

There were some limitations to the study. No attempt was made to identify whether students had previous encounters with persons living with HIV, either in a health care environment or via contact with family or acquaintances with HIV. Since this was a preliminary investigation, no follow-up was conducted to discern if student perceptions changed as a result of their participation. Some of the statements might have been confusing to students, making it difficult to discern whether they agreed. In some cases, compelling a student to choose between a forced dichotomy of agree or disagree might have hindered the authenticity of the response or inadvertently coerced a response that the student assumed to be the "correct" answer. The data may have been somewhat misrepresentative of students' true feelings and responses may not have been completely candid. Their responses might also have been influenced by knowing that the instructor specializes in the care of HIV patients.

Some pharmacy students will encounter persons living with HIV through a variety of experiences over the course of their professional training. ${ }^{29}$ A national educational platform exists to equip health care providers with foundational knowledge of the HIV care continuum. ${ }^{33}$ In light of the realization that HIV impacts subpopulations of society differently, increased cultural competency training, coupled with awareness of views held toward persons living with HIV, is paramount to facilitating impartial patient care. ${ }^{31,34}$

Prior to the learning activities described herein, students at this institution received no instruction in the curriculum about the stigmas experienced by persons living with HIV. Application of this instructional design has the potential to extend beyond the traditional didactic setting. The methods of exchange and dialogue are conducive to a variety of training and development situations. Many practitioners and trainees might possess misconceptions about persons living with HIV that could be effectively identified and addressed using a similar methodology.

\section{CONCLUSION}

Persons living with HIV are forced to deal with a variety of stigmas that are imposed on them by society. Pharmacy training programs should help students recognize the misperceptions about persons living with HIV that can dramatically impact how those patients relate to other people, including their health care providers. The findings in this study suggest that PharmD programs should incorporate opportunities for students to become aware of their own perceptions of HIV, learn about the challenges of living with HIV, and develop a more empathic perspective of how to serve the health care needs of that population.

\section{ACKNOWLEDGMENTS}

The author acknowledges Dan Brown, PharmD, from South University School of Pharmacy, and Richard F. O'brocta, PharmD, from University of Buffalo School of Pharmacy and Pharmaceutical Sciences for reviewing this manuscript and providing instructive comments.

\section{REFERENCES}

1. Miller CT, Solomon SE, Varni SE, et al. A transactional approach to relationships over time between perceived HIV stigma and the psychological and physical well-being of people with HIV. Soc Sci Med. 2016;162(1):97-105.

2. Li X, Wang H, He G, Fennie K, Williams AB. Shadow on my heart: a culturally grounded concept of HIV stigma among Chinese injection drug users. J Assoc Nurses AIDS Care. 2012; 23(1):52-62.

3. Culyba RJ, McGee BT, Weyer D. Changing HIV clinical knowledge and skill in context: the impact of longitudinal training in the southeast United States. J Assoc Nurses AIDS Care.

2011;22(2):128-139.

4. Woollett N, Cluver L, Hatcher AM, Brahmbhatt H. "To be HIV positive is not the end of the world:" resilience among perinatally infected HIV positive adolescents in Johannesburg. Child Youth Serv Rev. 2016;70(1):269-275.

5. Badahdah AM. Attitudes towards restricting the sexual and reproductive rights of women living with HIV infection in Yemen. $J$ Assoc Nurses AIDS Care. 2016;27(2):180-187.

6. Li L, Li-Jung L, Guoping J, Lin C, Xiao Y. Perceived bonding by parents living with HIV and their adolescent children. J Res Adolesc. 2015;26(4):880-888.

7. Rosenfield D, Ridge D, Catalan J. Age and life course location as interpretive resources for decisions regarding disclosure of HIV to parents and children: findings from the HIV and later life study. $J$ Aging Stud. 2016;38(1):81-91.

8. Rochat T, Netsi E, Redinger S, Stein A. Parenting and HIV. Curr Opin Psychology. 2017;15(1):155-161. 


\section{American Journal of Pharmaceutical Education 2020; 84 (10) Article 7270.}

9. Wattradul D, Sriyaporn A. Experiences of caregivers in healthcare for and social support of HIV positive children attending schools in Bangkok. Asian Nurs Res. 2014;8(3):226-231.

10. Semple SJ, Strathdee SA, Zians J, Patterson TL. Factors associated with experiences of stigma in a sample of HIV-positive, methamphetamine-using men who have sex with men. Drug Alcohol Depend. 2012;125(1-2):154-159.

11. Eldelman EJ, Cole CA, Richardson W, et al. Stigma, substance use and sexual risk behaviors among HIV-infected men who have sex with men: a qualitative study. Prev Med Rep. 2016;3(1): 296-302.

12. Wang W, Wang Y, Xiao C, et al. Psychological pathway to suicidal ideation among people living with HIV/AIDS in China; A structural equation model. Psychiatry Res. 2018;260(1):255-261. 13. Wesche-Szollosi DE, Ghoneim O, Edafiogho IO, Ofusu JR. Developing pharmacy student empathy using mock HIV antiretroviral therapy regimens: a learning activity. Curr Pharm Teach Learn. 2016;8(2):240-246.

14. Accreditation Council for Pharmacy Education. Guidance for the Accreditation Standards and Key Elements for the Professional Program in Pharmacy Leading to the Doctor of Pharmacy Degree ("Guidance for Standards 2016"). Published February 2015. https:// www.acpe-accredit.org/pdf/GuidanceforStandards2016FINAL.pdf. Accessed September 22, 2020.

15. Rickles NM, Furtek KJ, Malladi R, Ng E, Zhou M. Pharmacy students' attitudes and willingness to engage in care with people living with HIV/AIDS. Am J Pharm Educ. 2016;80(3):Article 45. 16. Jarvis M, Beall J, Woolley T. Knowledge and attitudes of pharmacy students towards human immunodeficiency virus (HIV). Curr Pharm Teach Learn. 2015;7(1):137-140.

17. Ahmed SI, Hassali MA, Aziz NA. An assessment of the knowledge, attitudes, and risk perceptions of pharmacy students regarding HIV/AIDS. Am J Pharm Educ. 2009;73(1):Article 15. 18. Tran A, Stewart AL, Covvey JR. Knowledge, attitudes and beliefs regarding human immunodeficiency virus and in-home testing among a regional sample of student pharmacists. Curr Pharm Teach Learn. 2017;9(6):980-988.

19. Waluyo A, Culbe GJ, Levy J, Norr KF. Understanding HIVrelated stigma among Indonesian nurses. J Assoc Nurses AIDS Care. 2015;26(1):69-80.

20. Rosenberg N, Taliaferro D, Ercole P. HIV-related stigma among nursing students in Cameroon. J Assoc Nurses AIDS Care.

2012;23(2):170-176.
21. Gagnon M. Re-thinking HIV-related stigma in health care settings: a qualitative study. J Assoc Nurses AIDS Care. 2015;26(6):703-719.

22. Rao D, Angell B, Lam C, Corrigan P. Stigma in the workplace: employee attitudes about people with HIV in Beijing, Hong Kong, and Chicago. Soc Sci Med. 2008; 67(10):1541-1549.

23. Gausset Q, Mogensen HO, Yameogo WE, Berthe A, Konate B. The ambivalence of stigma and the double-edged sword of HIV/ AIDS intervention in Burkina Faso. Soc Sci Med.

2012;74(7):1037-1044.

24. Balfour L, Corace K, Tasca GA, Best-Plummer W, MacPherson PA, Cameron DW. High HIV knowledge relates to low stigma in pharmacists and university health science students in Guyana, South America. Int J Infect Dis. 2010;14(10):e881-887.

25. Leyva-Moral JM, Terradas-Robledo RT, Feijoo-Cid M, et al. Attitudes to HIV and AIDS among students and faculty in a School of Nursing in Barcelona (Spain): a cross-sectional survey. Collegian. 2017;24(6):593-601.

26. Maina G, Sutankayo L, Chorney R, Caine V. Living with and teaching about HIV: engaging nursing students through body mapping. Nurse Educ Today. 2014;34(4):643-647.

27. Khan SA, Liew ML, Omar H. Role of ethical beliefs and attitudes of dental students in providing care for HIV/AIDS patients. Saudi Dent J. 2017;29(1):7-14.

28. Li R, Dong W, He W, Liu Y. Chinese dental students' knowledge and attitudes toward HIV/AIDS. J Oral Sci. 2016;11(1):72-78. 29. Badowski ME, Nyberg CR, Chaiyaperm V. Perceptions of pharmacy trainees completing a clinical experience in a HIV telemedicine clinic at an urban academic medical center. Curr Pharm Teach Learn. 2016;8(6):840-845.

30. Donnelly J, Donnelly M, Kittleson MJ, Fogarty KJ, Procaccino AT Jr, Duncan DF. An exploration of attitudes on sexuality at a northeastern urban university. Psychol Rep. 1997;81(2):677-678. 31. Centers for Disease Control and Prevention (CDC). https:// www.cdc.gov/hiv/statistics/overview/index.html. Accessed September 22, 2020.

32. Peate I, Suominen T, Valimaki M, Lohrmann C, Muinonen U. HIV/AIDS and its impact on student nurses. Nurse Educ Today. 2002;22(6):492 - 501.

33. National HIV Curriculum. https://www.hiv.uw.edu/. Accessed September 22, 2020.

34. AIDSVu. https://aidsvu.org/local-data/united-states/south/. Accessed September 22, 2020. 
American Journal of Pharmaceutical Education 2020; 84 (10) Article 7270.

\section{Appendix 1. Survey Items Primarily Evaluating Perceptions Toward Persons Living With HIV}

\begin{tabular}{|c|c|c|c|}
\hline I believe & I feel & I am comfortable & I avoid \\
\hline $\begin{array}{l}\text { 1. I believe couples living with } \\
\text { HIV should not have } \\
\text { permission to bear children. }\end{array}$ & $\begin{array}{l}\text { 6. I feel expensive health } \\
\text { services should omit PLWH } \\
\text { since they are at higher risk } \\
\text { of dying than the general } \\
\text { population. }\end{array}$ & $\begin{array}{l}\text { 11. I am comfortable with } \\
\text { counseling PLWH on proper } \\
\text { usage of their HIV } \\
\text { medications. }\end{array}$ & $\begin{array}{l}\text { 16. I avoid/would avoid dating } \\
\text { PLWH. }\end{array}$ \\
\hline $\begin{array}{l}\text { 2. I believe PLWH should } \\
\text { blame themselves. }\end{array}$ & $\begin{array}{l}\text { 7. I feel too much government } \\
\text { funding is devoted to HIV } \\
\text { research. }\end{array}$ & $\begin{array}{l}\text { 12. I am comfortable with my } \\
\text { name and picture being } \\
\text { associated with HIV } \\
\text { prevention efforts on the } \\
\text { internet. }\end{array}$ & $\begin{array}{l}\text { 17. I avoid/would avoid } \\
\text { discussing HIV topics with } \\
\text { my family and/or friends. }\end{array}$ \\
\hline $\begin{array}{l}\text { 3. I believe reducing the stigma } \\
\text { associated with HIV has } \\
\text { lessened the severity of the } \\
\text { disease. }\end{array}$ & $\begin{array}{l}\text { 8. I feel people who knowingly } \\
\text { contract HIV from their } \\
\text { partners should have to } \\
\text { undergo psychological } \\
\text { testing. }\end{array}$ & $\begin{array}{l}\text { 13. I am comfortable with } \\
\text { women sexually assaulted by } \\
\text { men living with HIV having } \\
\text { abortions. }\end{array}$ & $\begin{array}{l}\text { 18. I avoid/would avoid } \\
\text { placing my children in a } \\
\text { daycare center with children } \\
\text { living with HIV. }\end{array}$ \\
\hline $\begin{array}{l}\text { 4. I believe health care workers } \\
\text { living with HIV should } \\
\text { disclose their statuses to } \\
\text { their patients. }\end{array}$ & $\begin{array}{l}\text { 9. I feel commercial sex } \\
\text { workers deserve the highest } \\
\text { quality of healthcare } \\
\text { services. }\end{array}$ & $\begin{array}{l}\text { 14. I am comfortable offering } \\
\text { medical advice to a male } \\
\text { living with HIV who is } \\
\text { married to a woman but has } \\
\text { sex with men. }\end{array}$ & $\begin{array}{l}\text { 19. I avoid/would avoid } \\
\text { placing my elderly parents in } \\
\text { a facility with elderlies } \\
\text { living with HIV. }\end{array}$ \\
\hline $\begin{array}{l}\text { 5. I believe a cure for HIV } \\
\text { exists; however, it is } \\
\text { unavailable due to fear of } \\
\text { financial losses. }\end{array}$ & $\begin{array}{l}\text { 10. I feel inexpensive co- } \\
\text { payments should not apply } \\
\text { to HIV medications. }\end{array}$ & $\begin{array}{l}\text { 15. I am comfortable with the } \\
\text { idea of the Surgeon General } \\
\text { of the United States being a } \\
\text { PLWH. }\end{array}$ & $\begin{array}{l}\text { 20. I avoid/would avoid } \\
\text { engaging in sexual acts with } \\
\text { a PLWH whose viral load is } \\
\text { undetectable. }\end{array}$ \\
\hline
\end{tabular}

Abbreviations: HIV=human immunodeficiency virus, $\mathrm{PLWH}=$ persons living with HIV 